\title{
THEORETICAL EXPLORATION OF THE CAFE'S PROXEMICS AS A TRANSITIONAL EDUCATIONAL SPACE
}

\author{
Sakuntala Verlista ${ }^{1^{*}}$, Djuli Djatiprambudi ${ }^{2}$, I Nyoman Lodra ${ }^{3}$ \\ 1,2,3 Universitas Negeri Surabaya, Surabaya, Indonesia \\ 1*sverlista@gmail.com
}

\begin{abstract}
This paper was a theoretical exploration of proxemic discourse and the experience of cafe space as a transitional educational space. It was based on the development of a paradigm in the $21^{\text {st }}$ century that has targeted the cafe sector and provided the potential to be converted into an alternative educational space, especially for the millennial generation, called students. This study theoretically explored based on the phenomena seen at Yoman Cafe in Surabaya, Indonesia, which often became an alternative learning place for students at Universitas Negeri Surabaya. The research was conducted through participatory observations during March 2021, and it was analyzed by carrying out theoretical exploration of proxemics, spatial experiences, and alternative spaces. The results showed that the cafe currently had a dual role which was known as hybrid. Apart from being a cafe with the traditional definition of being a place to eat, the current cafe also had a role as an alternative space. This was based on the achievement of several aspects to create a sense of comfort as a transitional educational space, namely table settings that provided private space for visitors, comfortable and comprehensive furniture, selection of materials, ambiance entertainment, lighting and acoustics, colors, and use of aesthetic elements.
\end{abstract}

Keywords: theoretical exploration, cafe's proxemics, transitional educational space

\section{EKSPLORASI TEORETIS PROKSEMIKA KAFE SEBAGAI RUANG TRANSISI PENDIDIKAN}

\begin{abstract}
ABSTRAK
Tulisan ini merupakan eksplorasi teoritis dalam mewacanakan proksemika dan pengalaman ruang kafe sebagai ruang pendidikan transisional. Hal tersebut berlandaskan pada pengembangan paradigma di abad ke-21 yang menyasar sektor kafe dan memberikan potensi untuk diubah menjadi ruang pendidikan alternatif, terutama bagi generasi milenial yaitu mahasiswa. Penelitian ini mengupas secara teoritis berdasarkan fenomena yang terlihat di Yoman Cafe Surabaya, Indonesia yang sering menjadi alternatif tempat belajar bagi mahasiswa Universitas Negeri Surabaya. Penelitian dilakukan dengan melakukan observasi partisipatif selama Maret 2021, dan dianalisis dengan melakukan eksplorasi teoritis proksemika, pengalaman spasial, dan ruang alternatif. Hasil penelitian menunjukkan bahwa warnet saat ini memiliki peran ganda yaitu hybrid. Selain sebagai kafe dengan definisi tradisional sebagai tempat makan, kafe saat ini juga berperan sebagai ruang alternatif. Hal ini didasarkan pada pencapaian beberapa aspek untuk menciptakan rasa nyaman sebagai ruang edukatif transisional, yaitu penataan meja yang menyediakan ruang privat bagi pengunjung, furnitur yang nyaman dan lengkap, pemilihan material, suasana, pencahayaan dan akustik, warna, dan penggunaan elemen estetika.
\end{abstract}

Kata Kunci: eksplorasi teoritis, proksemika kafe, ruang pendidikan transisional

\begin{tabular}{|c|c|c|}
\hline Submitted & Accepted & Published \\
\hline 20 Mei 2021 & 09 Agustus 2021 & 14 September 2021 \\
\hline
\end{tabular}

\begin{tabular}{|l|l|l|l|}
\hline Citation & $:$ & $\begin{array}{l}\text { Verlista1, S., Djatiprambudi, D., \& Lodra, I. N. (2021). Theoretical Exploration of the Cafe's Proxemics as a Transitional } \\
\text { Educational Space. Jurnal PAJAR } \\
\text { http://dx.don.org/10.33578/pjr.v5i5.8416. }\end{array}$ \\
\hline
\end{tabular}

\section{INTRODUCTION}

The paradigm shift in the 21 st century does cover technological issues and targets spatial issues. Elizabeth Ellsworth, a media education researcher, investigated spatial issues which in the 21 st century accommodate, among others, the fields of technology, recreation, and education (Ellsworth, 2005). Furthermore, the issue of space and education shows the ability of the transitional education space. Transitional educational spaces provide flexible accessibility for users to carry out educational activities that negotiate with other activities. One of the transitional education spaces inspired by implicit and explicit pedagogical ambitions, among others, is the cafe.

Cafes are conceptually explored into the world of architecture, design, media, art, and 
education as a conceptual space that helps a person feel more spatially comfortable (Ellsworth, 2005). The experience of transitional educational space in a cafe can create disjunction or discontinuity in everyday life, especially for the millennial generation, which can be categorized as students in the current context. Such discontinuity forms the basis of a modern learning process that allows new relationships between the inner world (internal) and the external world (external) of students involved in the educational transition space (Ellsworth, 2005).

In this 21 st century, cafes have become an alternative place for students to study, discuss, or do activities related to their academic needs ( $\mathrm{Lu}$, 2010). Apart from changes related to space, it is also due to their boredom with the increasingly narrow space of educational institutions. The cafe, which at the beginning was only a hangout place, has now also been used as a place to work or an alternative place to study other than traditional schools. On the other hand, a feature that is almost similar to a restaurant owned by a cafe is not only a place to satisfy hunger and get service but also to get a different learning experience with a unique atmosphere (Lu, 2010).

The phenomenon of cafes as a transitional space for education has occurred in many regions in Indonesia. In this regard, Surabaya is also inseparable from the phenomenon in which cafes are transformed into transitional educational spaces. The existence of cafes in Surabaya has become an alternative to take advantage of free time or a place to study, as has been said before. Gathering at a cafe is a routine activity that is now easy to see in every corner of Surabaya. Therefore, it can be said that nowadays the cafe has become a second home for students. The students who visit this cafe can linger in studying, gathering, or just filling their spare time.

The arrangement of the cafe space is also seen as a place where students from all educational backgrounds can develop interactions. Furthermore, the arrangement of the cafe space also plays a role in establishing interaction between students as cafe visitors. The cafe interior styling model can accommodate structured activities that facilitate social interaction between visitors in a relaxed and unstructured way. The spatial arrangement arranged in such a way can make students as cafe visitors more comfortable to linger in the cafe. Lilly Lu stated that a cafe with a representative location selection and good accessibility, supported by soft and comfortable seating, can make visitors feel at home for prolonged sitting (Lu, 2010; Patton et al., 2020). This makes it easier for students as cafe visitors to interact. Furthermore, interactions are increasingly occurring because some cafe visitors are still communal (Lu, 2010, 2013).

The phenomenon where visitors get to know each other in a cafe has become common in Surabaya in recent years. Students as visitors began to be called loyal customers because they were considered already familiar with the workers at the cafe or other loyal visitors. So it is not surprising that there is an exciting chat in a cafe between groups of students as loyal visitors of a cafe. The conversations that occur are not always about academics but also in the form of light conversations. This indicates that the transformation of the cafe as a transitional educational space is individual and communal (Anderson, 2011).

In response to the above, various types of cafes have emerged to meet the community's needs, ranging from small individual cafes to cafes owned by large investors. Each cafe has an interior arrangement tailored to the target market and the concept raised by the manager. Spatial planning and the creation of a spatial experience are created to provide convenience to cafe users. This is related to the cafe market segmentation, a student as part of the millennial generation. Therefore, the cafe's interior design is generally understood as a meeting room that is comfortable, relaxed, friendly, and inclusive for young people with an age range of 15 to 30 years (Ruth, 2017). This utilization involves proxemics as the use of perceptions both in the social and personal sphere of a person, such as in seating and room arrangement, which in this study are students of the Universitas Negeri Surabaya.

Proxemics is interesting because it looks at it from an interior and spatial perspective and accommodates various disciplines such as art, 
culture, and psychology, and expands research in non-verbal communication (Ruth, 2017). In this study, proxemics is used to see a new dimension to see the phenomenon of the cafe space as a transitional educational space and non-verbal visitor interaction through its interior. This is related to the communal study groups that are often present in cafes. Student study groups that take place in the cafe make use of the physical space in interaction.

Other factors make it attractive, namely the adaptation of new habits, which are the solution options for the Covid-19 pandemic that has not ended. It is well known that in early 2020 the Novel Coronavirus, or from now on known as Covid-19, occurred and attacked various countries in the world (Sampurno et al., 2020). The city of Surabaya is one of the areas affected by the pandemic. The city government has also begun to implement a new habitual adaptation period that requires a protocol to adapt to the new normal order. For business owners, particular protocols must be implemented in order to run their business. Some of these protocols include providing a washing place outside the business premises, preparing hand sanitizers, and limiting visitors or workers.

Yoman's Cafe in Lidah Wetan, Surabaya, also follows this protocol. Even though the cafe design has been formed, it is not easy to change the previously conceptualized order. Another suggestion given by the government is to provide space between the seats for cafe visitors. The limitation of the distance in this cafe is an application of proxemics. One of the discussions in proxemics is about the space zone and the interaction distance. When associated with interior design, this proxemics discusses the space zone itself and can also be improved on the artistic aspects of interior spatial arrangement.

Based on the above problems, the first is about the position of cafes in the 21 st century as a transitional educational space which is focused on students of the Universitas Negeri Surabaya in three cafes around Lidah Wetan, Surabaya; second, about communal groups and the interactions that occur in them; and third, regarding the implementation of adaptation of new habits that affect proxemics, interactions, and cafe activities as a transitional educational space. Therefore, this research wants to investigate the problem of proxemics by looking at the phenomenon of cafes as a transitional educational space for students of the Universitas Negeri Surabaya. Furthermore, this cultural phenomenon can be seen from the interaction with the cafe's interior, namely by identifying the elements forming the space that exist in each predetermined cafe. This space-forming element in the form of floors, walls, and ceilings can be an indicator in reading the changes that have been made by cafe managers related to the adaptation of new habits. The arrangement of the cafe space also affects the spatial experience of cafe space users, especially in its use as a transitional educational space. In addition to using proxemics, reading spatial experiences were obtained from students of the Universitas Negeri Surabaya as cafe users. The students' spatial experiences are read through their perceived sensory perceptions so that by dissecting the interior of the cafe and relating it to spatial experiences, new things can be learned that emerge during the adaptation of new habits.

\section{RESEARCH METHODS}

This study explores theoretically based on the phenomena seen at the Yoman Cafe in Surabaya, Indonesia, which is often an alternative learning place for students at the State University of Surabaya. Therefore, this study uses the concept of a content analysis approach about proxemics, spatial experiences, and alternative educational spaces (Leavy, 2017; Orakci, 2020; Tashakkori \& Creswell, 2008). The research was conducted by conducting participatory observations during March 2021, and it was analyzed by carrying out theoretical exploration of proxemics, spatial experiences, and alternative spaces. The participatory observation was conducted at Yoman Cafe in Surabaya, Indonesia. Yoman Cafe was chosen because it has regular visitors who use it as a transitional educational space. This information was obtained from researchers as participatory observants, and conversations with cafe managers. On the other hand, along with participatory exploration of phenomena, theoretical exploration 
is also carried out based on the grand theory of proxemics, spatial experiences, and alternative educational spaces. The two models above are carried out interactively so that later findings will be obtained from theoretical exploration of proxemics and spatial experiences in cafes as an alternative educational space. The theoretical basis is an essential aspect in research which is also referred to as a theoretical framework (Lune \& Berg, 2017). In the sense that the fundamental essence of a theory in research is not just a basic concept for predicting a problem in research, but a theory also acts as a basic framework to make it easier for researchers to see, describe, and reveal the problems being studied. The theory is a collection of concepts, definitions, and systematically interrelated propositions developed to explain and predict phenomena or (facts) (Cooper \& Schindler, 2003). Some of the theories that will be used as basic concepts and frameworks of exploration and thought to answer the problems in the research are proxemics and spatial experiences, and public space education.

\section{RESULTS AND DISCUSSION}

According to Hall, proxemics is the study of how humans unconsciously structure the microdistance space between humans in carrying out daily transactions, the organization of space in homes and buildings, and ultimately urban planning (Hall, 1966). Proxemics can also be explained as a study that examines human perceptions of space (personal and social), how humans use space, and the influence of space in communication (Hall et al., 1968). Hall also stated that not necessarily all concepts about messages in space can be represented by interior elements so that other supporting factors are needed to convey interactions in space (Hall, 1966). In interior design studies related to educational space, space and distance are closely related to human interactions based on specific cultural characteristics (Deng et al., 2017; Wang et al., 2019). Therefore, spatial planning becomes an indirect interaction to provide information to students as users of the educational transition space.
In the book The Hidden Dimension (1966), Hall divides two categories of proxemic descriptions that can be used as a basis for research, namely interpersonal space and distance (Hall, 1966). Hall (in Laurens, 2005) divides it into several more sections to the category of space (Laurens, 2005). The basic form of interpersonal space is divided into three, namely

1. Fixed space formed by walls and territorial boundaries;

2. Semi-fixed space, which is covered by a relatively fixed divider and not easy to shift, for example, such as floors, walls, and ceilings; and

3. Informal spaces that are dynamic that are manifested when someone makes variations from interpersonal space or space.

By identifying these spatial patterns, interior designers can determine the grouping of space boundaries that can create coordinating spaces that provide privacy and comfort for its users. When the context is placed in the cafe as a transitional educational space, it requires supporting elements and ambiance concepts that need to be provided to support the convenience of visitors as an educational transition space.

Cafes as transitional educational spaces also consider interpersonal distance. Hall divides the four categories of distance, namely close distance, personal distance, social distance, and public distance (Hall, 1966). A close distance in the $<0.5$-meter range is commonly used with intimate people or people who are considered close acquaintances. The physical presence of other people at a close distance is considered distracting. Furthermore, at a close distance, the interaction can also occur by feeling the temperature, smell, and touch of the other person. Based on these points, it can be said that at a close distance, a person can be emotionally involved with another person who is the opponent of the interaction, and his feelings as a visitor can change according to mood (Beckers et al., 2016). The category of close distance can occur if there is a deliberate condition and an attraction between the two interacting people.

The next category is the personal distance which has a range of 0.5 meters to 1.5 meters. At this personal distance, the visitor's eyes begin to 
focus, and the sounds they make begin to have a verbal meaning. This distance is the interaction distance that good friends tend to use and the most appropriate distance to discuss personal and other essential matters. However, in some instances, this distance is also applied by people who do not know each other for some reason and applied by study groups who have met for the first time or do not yet have communal intimacy (Brady et al., 2018; Moran et al., 2018).

After close and personal distance, the following distance is social distance, commonly referred to as psychological distance. Social distance has a range of $1.5-3$ meters. On social distancing, a visitor begins to get anxious when someone else enters his or her boundaries. In the social distance, someone can hear and see clearly and is commonly used in meetings or meetings that occur in an office or other meeting places (Fielding, 2016). Even though visitors start to feel anxious at this distance, there is no need to worry too much about the presence of other people.

Furthermore, as a person who belongs to other people's territory, there is also the option of not being involved in the conversations carried out by those around them. Social distance in the cafe is taken into account by arranging interior elements, such as tables and chairs and some partitions used to limit the visitors' space. It is used to provide comfort and intimacy by the concept of a cafe as a transitional educational space that accommodates intimate matters both individually and in groups (Anderson, 2011).

The last division of distance in a room is the public distance with a range of more than 3 meters. This distance applies to a person or group of strangers. At a public distance, one can understand the nuances of the meaning of the face or the intonation of other people's voices from the view of the overall physical form of one's body and face in the public distance (Handa, 2013).

From the distance categorization above, it can be explained that the status of a visitor in space can affect the application of the proxemic distance. The more you have equal status, the closer you will be to people with different statuses. The problems that occur participate in the affecting distance. The more intimate the visitor's interaction, the closer the distance is created. Differences in gender and age also create distance. A person of the same sex will usually be close to each other. When you have close ties, sex differences are sometimes overlooked in close relationships. Not only that, positive and negative judgments also play a role in forming distance. This becomes the basis for how distance affects the comfort of students to study in cafes. These relationships are intertwined with the communal aspects of studying, such as study groups in cafes.

It reconstructs the concept of learning that takes place in a formal space regarding distance and relations in space. However, this has begun to be recontextualized by providing classrooms with various learning facilities that support new learning activities (Gude, 2013, 2018). These new learning spaces show remarkable similarities to the use of public spaces / third places / public spaces such as coffee shops, cafes, restaurants, and public open spaces as study spaces. The distance used to interact in the public sphere has shifted to become public-private in a negotiative manner (Hall, 1966).

The shift in the distance is also caused by technological developments where students and students can study anywhere and anytime. In line with this trend, every meter2 of the built environment can support learning activities. Like the analogy of "the city is an office" (Harrison, 2002: 248), "the cafe is a place of learning" (den Heijer \& Curvelo Magdaniel, 2012: 3), the third place is the study room. The choice of particular learning spaces is related to the physical and social perceptions and comfort of a place compared to other places due to environmental psychology, which further explores the physical and social dimensions of the learning environment in the transitional educational space.

A building built for learning but is poorly designed can hold someone back from coming and learning (Thoring et al., 2018), while a welldesigned building can attract someone to learn (Sloane, 2014). The physical aspects of the learning environment can influence interest in learning, especially regarding comfort and aesthetics. These aspects are related to lighting, air quality, temperature, acoustics, furniture, and 
color. The perceptual attribute of visitors who use the cafe as a place to study is strongly influenced by the cafe's design (Wang et al., 2019).

For informal study spaces, Harrop and Turpin found that visitors often described lighting and natural light as necessary (Harrop \& Turpin, 2013). Comfortable furniture that can be reconfigured in a functional space has a vital role because it has to do with distance. The aesthetic aspect also deals with interior design elements, such as color schemes, floor types, and decorative features. In addition, natural elements are needed in the learning environment to engage visitors as their learning environment, such as indoor murals, natural landscapes, and plants (Harrop \& Turpin, 2013).

The layout is also needed about the physical environment to facilitate the flow of visitors between learning areas and enjoying meals in cafes in an area, both individually and with other people. There is a spatial relevance about learning in cafes as a transitional educational space. Somerville and Collins found that visitors prefer an open and unrestricted learning environment, where visitor ratings depend on spatial attributes, especially visibility, technological facilities, and other facilities provided (Somerville \& Collins, 2008). Based on the explanation above, the physical dimension in research on proxemics and spatial experience in cafes as a transitional educational space is operationalized in the above discussion.

In this study, the application of distance in a cafe has considered the things described above. However, the description of the distance will later be reviewed with the situation of the cafe, which is the setting of this research, namely Yoman Cafe, who are in Lidah Wetan, Surabaya. Proxemics in this study is also used to look back on the zone and distance in the arrangement of the cafe space that responds to the adaptation period of new habits. The formation of these zones is seen through the cafe's interior design, where the elements that form the space are used to help identify the problems raised in the research.

Apart from the proxemics and complexity involved in it, this study uses a theory of spatial experience. Yi Fu Tuan said that experience is an all-encompassing term for the various modes by which a person knows and constructs reality (Yifu, 1977). These modes range from more direct and passive senses of smell, taste, and touch to active visual perception and indirect symbolization modes. Therefore, to understand the spatial experience in a cafe as a transitional educational space, this study uses an approach to the formation of a cafe's space atmosphere and human perceptions. Combining these approaches is expected to help researchers in reading about spatial experiences that occur during the adaptation period of new habits, especially in a cafe as a transitional educational space for students of the Universitas Negeri Surabaya.

According to Mill, the atmosphere is the overall atmosphere created by a restaurant to increase visits (Kassing, 2016; Mill, 2007). A person's decision to study in a transitional educational room is not only based on the needs of the selected companion menu but also on physical experience as manifested in the atmosphere. The room atmosphere is formed from various elements, some of which are activities of space users. Through the combination of these elements, the atmosphere of the space can form a unique spatial experience for the customer or user of the space. In this regard, the three cafes that are the research locations are cafes often used by students to study. The cafe's interior design, which is used as a transitional educational space, aims to provide something attractive to its visitors. An attractive design that fits your needs is expected to become one of the trajectories of the cafe to attract customers. Based on this, we can categorizes several elements of a restaurant atmosphere that can be processed through interior design arrangements. The elements forming the atmosphere of a restaurant that provide transitional space of education consist of:

1. Table Settings

The table setting in the transitional educational space is an initial impression seen by visitors. The table arrangement is necessary because it can create a cafe atmosphere and provide boundaries. The table arrangement in question is the arrangement of the table support elements. In this study, the arrangement of cafe tables is not as 
complex as table setting in a restaurant, so that table settings tend to discuss table settings that support transitional educational spaces.

2. Furniture

The choice of furniture and its placement is something important in a cafe. The furniture can indirectly form its own experiences related to the educational aspects for visitors.

3. Surface Material

The material in the cafe space can create an attractive atmosphere in a cafe. This impacts the exclusivity aspect of the cafe, which in this study looks for a correlation about cafes as a transitional educational space (Cys \& Lawrence, 2013).

4. Ambience entertainment

In a cafe, entertainment becomes an important thing. This reminds us of the Pomodoro learning model, which implements the concept of ambiance to provide an educational feel wherever Pomodoro is implemented (Ghavifekr \& Rosdy, 2015; Hudson, 2020). Entertainment in the form of music can affect the atmosphere of the space, which later can impact consumer behavior (Folkestad, 2005).

\section{Distance and Lighting}

The choice of the lighting system is very influential in the formation of visitors' perceptions of the cafe as a transitional educational space. Natural and artificial lighting can be combined to shape the educational experience and behavior of the cafe goers.

6. Color

Color can play a psychological role for the user of the space. Color in a restaurant space can give a sense of relief or vice versa. The theory of color in a cafe as a transitional educational space refers to social, cultural, and biological aspects (Elliot, 2015). Some responses to color stimulation are considered solely due to a repeating spectrum of colors supported by certain concepts, messages, and experiences constructed by the cafe manager. Therefore, the color association can extend beyond the visitor's natural process into the visitor's internal perceptual process.

The following approach is about space perception, which is not interpreted as just space but a product that cannot be separated by human activity (Sloane, 2014). Space can be felt with sensory tools, consisting of two categories: distance receptors and immediate receptors (Hall et al., 1968; Sumartono, 2007). Distance receptors consisting of the eyes, ears, and nose are used to examine objects and sensations that are far away, while immediate receptors consisting of skin, membranes, and muscles are used to examine near and direct objects (Hall, 1966; Hall et al., 1968). Based on this opinion, the cafe space as a transitional space for restaurant education can be perceived as (1) Distance receptors which include visual space, where the visual perspective is influenced by the eye structure and the angle where the object is seen. The retina, which is part of the eye, functions as a peripheral vision that can recognize the situation around it or what is commonly referred to as broad vision (McKellar, 2015), (2) Auditory space, which is closely related to hearing or more precisely about noise levels. The noise level in question originates from kitchen activities such as conversations between employees, processing to serving food before it reaches consumers. There are several ways to reduce the noise level, namely acoustic panels, decorative materials and playing background music, and (3) Olfactory space, which deals with the sense of smell. The section about the olfactory space has received little attention. At the same time, the aroma can evoke pleasure and memories for visitors about cafes as a transitional educational space (Hall et al., 1968). In the case of this study, which focuses on cafes, the aroma is one of the tools to market products and add a sense of calm for visitors (Michels et al., 2018).

Although this research relies on fine arts education, the topic of cafes as a space for educational transition is still included in the scope of scientific disciplines. Therefore, functional studies from environmental and social sciences are needed to support research, including public space education, aesthetics, and art space activities.

Education underlines the awareness and understanding of individuals about environmental relations that support and interact with each other (Ardoin et al., 2020). The appearance of publicbased educational spaces represents social values communicated through visual messages, which influence cafe managers' decisions (Zingoni, 
2018). The cafe manager must determine the design activities in performing the perceptions needed to achieve the desired appearance and how these activities will impact learning activities in the cafe.

\section{CONCLUSIONS AND RECOMMENDATION}

We want to start with the relationship between cafes and the Covid-19 pandemic, which has openly changed and transformed various sectors of activity. There needs to be a new adaptation so that this breakthrough life can work under this pandemic condition. New strategies are needed to stay afloat in this condition. Yoman Cafe, as the food and beverage industry affected by Covid-19, must adapt to this change. Yoman Cafe has adjusted its spatial arrangement, especially for the customer seating area, to comply with health protocols. The reading of proxemics in this study is used to act as a liaison for researchers in explaining spatial experiences and their theoretical explorations so that the discussion of proxemics is more on the visible physical arrangement.

The adjustment of the health protocol to the conditions in the Yoman Cafe field is the key to the success of this spatial planning. It can be seen in the arrangement of semi-fixed feature space elements, tables, chairs, and furniture that can be moved as needed; cafe managers are not careless in arranging them, but they see their customers' space needs and habits. So that even though there is a shift in communication distance, customers can still receive it well and even adapt to it. When talking about the spatial experiences felt by visitors during this new habituation period. It can be said that customers have started to adapt to the spatial arrangement and atmosphere that occurred during the adaptation period of this new habit. However, it requires a process that is not short. Spatial arrangement affects the formation of visitors' experience, but what is more important is the presence of a spatial atmosphere that supports the overall atmosphere of the cafe. The atmosphere of the space does not only arise because of the arrangement but also requires activities in it that participate in building experiences for customers. With the emergence of a pleasant customer experience, a cafe will still be visited by customers in any condition, provided that the quality of taste and service is maintained. Therefore, in managing a room, cafe managers need to know the details of the space users. By knowing the details well, the spatial arrangement will be more optimal. That way, space users can carry out their activities appropriately and can form a good space atmosphere. This good atmosphere of space by space users will later become an impressive experience for space users. When connected to the case of a cafe, a good experience will make a customer loyal to a cafe, and it is all based on the achievement of several aspects to create a sense of comfort as a transitional educational space, namely table settings that provide private space for visitors, comfortable and comprehensive furniture, selection of materials, ambiance entrainment, lighting and acoustics, colors, and use of aesthetic elements.

\section{REFERENCES}

Anderson, L. (2011). Use the World Café concept to create an interactive learning environment. Education for Primary Care, 22(5), 337-338. https://doi.org/10.1080/14739879.2011.11 494028

Ardoin, N. M., Bowers, A. W., \& Gaillard, E. (2020). Environmental education outcomes for conservation: A systematic review. Biological Conservation, 241(August 2019), 108224. https://doi.org/10.1016/j.biocon.2019.108 224

Beckers, R., van der Voordt, T., \& Dewulf, G. (2016). Learning space preferences of higher education students. Building and Environment, 104, 243-252. https://doi.org/10.1016/j.buildenv.2016.05 .013

Brady, B., Forkan, C., \& Moran, L. (2018). Spaces of connection and belonging: young people's perspectives on the role of youth cafés in their lives. Child Care in Practice, 24(4), 390-401. 
https://doi.org/10.1080/13575279.2017.12 99110

Cooper, D. R., \& Schindler, P. S. (2003). Business Research Methods. McGraw Hill.

Cys, J., \& Lawrence, J. (2013). A place at the table: Interiors and the everyday. Interiors: Design, Architecture, Culture, 4(3), 295314. https://doi.org/10.2752/204191213X1381 7427789316

Deng, Q., Allard, B., Lo, P., Chiu, D. K. W., SeeTo, E. W. K., \& Bao, A. Z. R. (2017). The role of the library café as a learning space: A comparative analysis of three universities. Journal of Librarianship and Information Science, 51(3), 823-842. https://doi.org/10.1177/096100061774246 9

Elliot, A. J. (2015). Color and psychological functioning: a review of theoretical and empirical work. Frontiers in Psychology, 6 , 368. https://www.frontiersin.org/article/10.338 9/fpsyg.2015.00368

Ellsworth, E. (2005). Places of Learning: Media, Architecture, Pedagogy. Taylor \& Francis Books, Inc. https://doi.org/10.4324/9780203020920

Fielding, H. (2016). "Any time, any place": The myth of universal access and the semiprivate space of online education. Computers and Composition, 40, 103-114. https://doi.org/10.1016/j.compcom.2016.0 3.002

Folkestad, G. (2005). Here, there and everywhere: music education research in a globalised world. Music Education Research, 7(3), 279-287.

https://doi.org/10.1080/146138005003243 90

Ghavifekr, S., \& Rosdy, W. A. W. (2015). Teaching and learning with technology: Effectiveness of ICT integration in schools. International Journal of Research in Education and Science, 1(2), 175-191. https://doi.org/10.21890/ijres.23596
Gude, O. (2013). New School Art Styles: The Project of Art Education. Art Education, 66(November 2017), 1-15.

Gude, O. (2018). Principles of Possibility: Considerations for a 21st-century Art and Culture Curriculum. Art Education, 60(1), 6-17.

Hall, E. T. (1966). The Hidden Dimension. Doubleday.

Hall, E. T., Birdwhistell, R. L., Bock, B., Bohannan, P., Diebold, A. R., Durbin, M., Edmonson, M. S., Fischer, J. L., Hymes, D., Kimball, S. T., La Barre, W., Frank Lynch, S. J., McClellan, J. E., Marshall, D. S., Milner, G. B., Sarles, H. B., Trager, G. L., \& Vayda, A. P. (1968). Proxemics. Current Anthropology, 9(2/3), 83-108. http://www.jstor.org/stable/2740724

Handa, R. (2013). Sen no Rikyū and the Japanese way of tea: Ethics and aesthetics of the everyday. Interiors: Design, Architecture, Culture, 4(3), 229-247. https://doi.org/10.2752/204191213X1381 7427789190

Harrop, D., \& Turpin, B. (2013). A Study Exploring Learners' Informal Learning Space Behaviors, Attitudes, and Preferences. New Review of Academic Librarianship, 19(1), 58-77. https://doi.org/10.1080/13614533.2013.74 0961

Hudson, T. D. (2020). Conversation as an Education Medium for the Age of Distraction - the 'Art of Range' Podcast. Rangelands, 42(1), 9-16. https://doi.org/10.1016/j.rala.2020.01.005

Kassing, J. E. (2016). An Application of Proxemics to Restaurant Interior: Tabletop Cooking and Its Implications for The Milenial User [Iowa State University]. https://lib.dr.iastate.edu/etd/14968/

Laurens, J. M. (2005). Arsitektur dan Perilaku Manusia. Grasindo.

Leavy, P. (2017). Research Design: Quantitative, Qualitative, Mixed Methods, Arts-Based, and Community-Based Participatory Research Approaches. The Guilford Press. 
Lu, L. (2010). Teaching 21st-Century Art Education in a Virtual Age: Art Café @ Second Life. Art Education, 63(6), 19-24.

Lu, L. (2013). 3D Virtual Worlds as Art Media and Exhibition Arenas: Students' Responses and Challenges in Contemporary Art Education. Studies in Art Education, 54(3), 232-245.

Lune, H., \& Berg, B. L. (2017). Qualitative Research Methods for the Social Sciences (Ninth edit). Pearson.

McKellar, S. (2015). Contested Spaces: The Problem with Modern Psychiatric Interiors. Interiors, 6(1), 21-39. https://doi.org/10.2752/204191115x14218 559960150

Michels, M., Storgaard, E., \& Somers, I. (2018). Back to basics in interiors education: The morphology of interior space. Interiors: Design, Architecture, Culture, 9(3), 261281.

https://doi.org/10.1080/20419112.2019.15 89691

Mill, R. C. (2007). Restaurant management: customers, operations, and employees. Pearson, Prentice Hall.

Moran, L., Brady, B., Forkan, C., \& Coen, L. (2018). 'Individual and connected': an exploration of young people's discourses about youth cafes in Ireland. Journal of Youth Studies, 21(8), 1127-1139. https://doi.org/10.1080/13676261.2018.14 41981

Orakci, Ş. (2020). Postgraduate students' expectations of their lecturers. Qualitative Report, 25(1), 199-215.

Patton, R., Sweeny, R. W., Shin, R., \& Lu, L. (2020). Teaching Digital Game Design With Preservice Art Educators. Studies in Art Education, 61(2), 155-170. https://doi.org/10.1080/00393541.2020.17 38165

Ruth, J. (2017). Designing Experience. Interiors: Design, Architecture, Culture, 8(1-2), 5366.

https://doi.org/10.1080/20419112.2017.13 27126
Sampurno, M. B. T., Kusumandyoko, T. C., \& Islam, M. A. (2020). Budaya Media Sosial, Edukasi Masyarakat, dan Pandemi COVID-19. SALAM: Jurnal Sosial Dan Budaya Syar-I, 7(5). https://doi.org/https://doi.org/10.15408/sjs bs.v7i5.15210

Sloane, M. (2014). Tuning the space: Investigating the making of atmospheres through interior design practices. Interiors: Design, Architecture, Culture, 5(3), 297 314.

https://doi.org/10.2752/204191114X1412 6916211184

Somerville, M. M., \& Collins, L. (2008). Collaborative design: a learner-centered library planning approach. The Electronic Library, 26(6), 803-820. https://doi.org/10.1108/026404708109215 92

Sumartono. (2007). Proksemika/Semiotika Ruang sebagai Sebuah Pendekatan untuk Penelitian Desain Interior. Lintas Ruang, 1(1), 1-5.

Tashakkori, A., \& Creswell, J. (2008). Mixed Methodology Across Disciplines. Journal Of Mixed Methods Research, 2(1), 1-5.

Thoring, K., Desmet, P., \& Badke-Schaub, P. (2018). Creative environments for design education and practice: A typology of creative spaces. Design Studies, 56, 54-83. https://doi.org/10.1016/j.destud.2018.02.0 01

Wang, Y., Deng, Q., \& Ji, S. (2019). Understanding Café Culture: Toward a Dynamic and Holistic Research Framework. Journal of Global Marketing, 32(1), 37-48. https://doi.org/10.1080/08911762.2017.14 20838

Yi-fu, T. (1977). Space and Place: The Perspective of Experience. University of Minnesota Press.

https://search.library.wisc.edu/catalog/999 493802702121

Zingoni, M. (2018). Prototyping process: interior architecture as a social agency. Interiors: Design, Architecture, Culture, 9(3), 306- 
Jurnal PAJAR (Pendidikan dan Pengajaran)

Volume 5 Nomor 5 September 2021 | ISSN Cetak : 2580 - 8435 | ISSN Online : 2614 - 1337

DOI : http://dx.doi.org/10.33578/pjr.v5i5.8416

323.

https://doi.org/10.1080/20419112.2019.16

22234 